\section{Category}

Chemistry in

Medicine and

Biology

\section{Key words}

antibodies

drug delivery

cancer

chemotherapy

P. R. HAMANN*, L. M. HINMAN, I. HOLLANDER, C. F. BEYER, D. LINDH, R. HOLCOMB, W. HALLETT, H.-R. TSOU, J. UPESLACIS, D. SHOCHAT, A. MOUNTAIN, D. A. FLOWERS, I. BERNSTEIN (CELLTECH CHIROSCIENCE, BERKSHIRE, UK; WYETH-AYERST RESEARCH, PEARL RIVER AND FRED HUTCHINSON CANCER RESEARCH CENTER, SEATTLE, USA) Gemtuzumab Ozogamicin, A Potent and Selective Anti-CD33 Antibody-Calicheamicin Conjugate for Treatment of Acute Myeloid Leukemia

Bioconjugate Chem. 2002, 13, 47-58.

\title{
The First FDA-Approved Antibody-Drug Conjugate
}<smiles>CC(=O)c1ccc(OCCCC(=O)O)cc1</smiles>

hydrazone formation

Significance: The enediyne-containing antitumor antibiotic calicheamicin induces double-stranded DNA breakage and is highly cell-toxic. Conjugation of calicheamicin to a humanized monoclonal antibody against CD33, an adhesion protein that is expressed on the cell surface of leucoblasts, allows its targeted delivery to the non-solid tumor acute myeloid lymphoma (AML). This construct was the first FDA-approved antibody-drug conjugate (ADC) and was marketed as Mylotarg. It was retracted in 2010; however, calicheamicin ADCs have now been reevaluated as therapeutic.
Comment: $N$-Ac- $\gamma$ was linked via a hydrazone to lysine residues on a humanized monoclonal antibody against the tumor antigen CD33 and succumbs to hydrolytic hydrazone cleavage upon endocytosis. The conjugation of calicheamicin to an antibody was previously reported (Cancer Res. 1993 $53,3336)$ and, here, the authors investigate different linkers to produce a more potent and selective agent. 